\title{
Evaluation of antimicrobial and antitumoral activity of Garcinia mangostana L. (mangosteen) grown in Southeast Brazil ${ }^{1}$
}

\author{
Bruna Lais Almeida Cunha', Jerônimo Pereira de França', Andrea Aparecida de Fátima Souza Moraes ${ }^{\mathrm{III}}$, Alba Lucilvânia \\ Fonseca Chaves ${ }^{\text {II }}$, Silvana Gaiba ${ }^{\text {IV }}$, Renato Fontana ${ }^{\text {II }}$, Celio Kersul do Sacramento ${ }^{\text {V }}$, Lydia Masako Ferreira ${ }^{\text {VI }}$, Lucimar Pereira \\ de França ${ }^{\text {II }}$
}

DOI: http://dx.doi.org/10.1590/S0102-86502014001400005

${ }^{\mathrm{I}}$ Graduate Student, Department of Biological Sciences, Universidade Estadual de Santa Cruz, Ilhéus-BA. Technical procedures.

IIPhD, Associate Professor, Department of Biological Sciences, Universidade Estadual de Santa Cruz, Ilhéus-BA. Scientific and intellectual content of the study, interpretation of data and critical revision.

IIIPhD, Volunteer Faculty, Department of Biological Sciences, Universidade Estadual de Santa Cruz, Ilhéus-BA. Technical procedures, acquisition and interpretation of data.

${ }^{\text {IV }} \mathrm{PhD}$, Fellow Pos-PhD degree, Department of Biological Sciences, Universidade Estadual de Santa Cruz, Ilhéus-BA. Technical procedures, acquisition and interpretation of data, manuscript writing.

${ }^{v} \mathrm{PhD}$, Associate Professor, Departament of Agricultural and Environmental Sciences, Universidade Estadual de Santa Cruz, Ilhéus-BA. Interpretation of data and critical revision.

${ }^{\mathrm{V}}$ Head and Full Professor, Plastic Surgery Division, UNIFESP, Researcher 1A-CNPq, Director Medicine III-CAPES, Sao Paulo-SP, Brazil. Interpretation of data and critical revision.

\section{ABSTRACT}

PURPOSE: To characterize the anatomy of the fruit and leaf and the presence of phytocompounds. To evaluate the antitumor and antimicrobial activity of ethanolic extract of Garcinia mangostana L. (mangosteen) cultivated in southeastern Brazil.

METHODS: Anatomical characterization and histochemical reactions were performed for structural identification and the presence of phytocompounds. Preparation of ethanolic extract of the fruit, leaf and resin of mangosteen. Culture B16-F10 melanoma cells for treatment with mangosteen ethanolic extract to determine cell viability by MTT and genotoxic effect by comet assay. Evaluation by antimicrobial activity against Staphylococcus aureus and Escherichia coli by agar diffusion test and by determination of Minimum Inhibitory Concentration (MIC).

RESULTS: Our results showed many secretory canals in resin fruit and leaf; identifying lipids, starch, lignin and phenolic compounds. The leaf extract induced genotoxicity and apoptosis in B16-F10 cells, since the fragmentation of DNA in the comet assay. The ethanolic extract of mangosteen obtained in the resin, leaf and fruit showed antimicrobial activity against Staphylococcus aureus and Escherichia coli with a MIC at $0.1 \mathrm{mg} / \mathrm{mL}$.

CONCLUSION: In conclusion, we have demonstrated both antimicrobial and antitumor activity of ethanol extract of mangosteen emphasizing its therapeutic potential in infectious diseases and in cancer, such as melanoma.

Key words: Garcinia mangostana L.; Drug Screening Assays, Antitumor; Anti-Infective Agents; Antimicrobial 


\section{Introduction}

Cutaneous melanoma is considered the most serious type of skin cancer. It is a highly lethal and very invasive neoplasm, accounting for less than $5 \%$ of all skin cancer cases. Despite its low incidence, it is considered a problem for public health due to the significant raise in the number of cases, exceeding other malignancies growth rate re $^{1-3}$.

In the last few years there has been growing interest in natural products with biological activity, with relevance to anticancer activity. A large diversity of plants has been extensively investigated, these plants being secondary metabolite producers. These studies on the biotechnological potential of plants sources promising therapeutic agents are mentioned, with antibacterial, antiviral, antitumor and immunossupressive potential ${ }^{3,4}$.

Garcinia mangostana L. (mangosteen) is a plant of Asian origin, belonging to the family Clusiaceae. It was introduced into Brazil in 1935 in Bahia, where it is still cultivated ${ }^{5}$. In some populations, especially in their countries of origin, the dried and ground mangosteen rind is used for medicinal purposes against dysentery and chronic diarrhea, besides being used as a homemade dye due to its color ${ }^{6,7}$. The biological activity of the mangosteen is subject of major scientific research, and its pericarp (rind) has been the main structure under study, demonstrating antioxidant ${ }^{8}$, antimicrobial ${ }^{9}$ and antidepressant activities ${ }^{10}$. Considering the therapeutic potential of the plant, this study aimed to characterize the morphological aspects of Garcinia mangostana L. cultivated in Southern Bahia and to evaluate its antimicrobial and antitumoral activity.

\section{Methods}

\section{Plant materials and preparation of ethanolic extract}

The leaf, fruit and resin of Garcinia mangostana L (mangosteen) collection was carried out in the city of Una, Southern region of Bahia, Brazil. Voucher specimens were deposited in the Herbarium of Department of Biological Sciences, University Estadual de Santa Cruz, Bahia, Brazil. The samples were washed with running tap water and separated before the fruit was chopped into pieces. They were oven-dried at $42^{\circ} \mathrm{C}$ for 5 days and ground to powder.

Plant materials used in this study were fresh fruits (seedless without core), leaf and resin of Garcinia mangostana L. The preparation of $70 \%$ ethanolic extract of dried plant was obtained by grinding and exposure to organic solvent for 8 days. A suspension of dried fruit $(50 \mathrm{~g})$ in water $(150 \mathrm{~mL})$ was extracted with ethanol $(350 \mathrm{~mL})$. Then, a rotary evaporator was used to remove the remaining alcohol and the aqueous layer and then followed by lyophilization to give water-soluble fractions.

\section{Extraction of gamboge resin}

The yellow exudate from the pericarp of the mangosteen fruit known as gamboge ${ }^{11}$ resin was obtained after cooling and centrifuging the extract and removing alcohol, which resulted in the precipitation of resin and an aqueous supernatant purple color similar to the external appearance of mangosteen. To ensure the quality of separation of the sample, successive washes and centrifugations was taken until the characteristic yellow color prevailed and there were no other traces of dye.

\section{Anatomical study of the mangosteen pericarp}

For the anatomical description of the mangosteen pericarp, $10 \mu \mathrm{m}$ thick sections were obtained with a rotatory microtome, and the mounted slides were stained with Astra blue and Safranin. The sections were analyzed in Photonic Microscopy (Axiostar model plus, ZEISS), x 200 magnification.

\section{Histochemical of mangosteen pericarp and leaves}

The mangosteen pericarp of the fruit and leaves were analyzed for compounds by histochemical reactions with Sudam III, Ferric chloride, Lugol and phloroglucinol acidified for identification of lipids phenolics, starch and lignin, respectively. The freehand cuts were performed with the help of razor (Gillette ${ }^{\circledR}$ ) and placed in contact with the reagent. The micrographs were obtained in Photonic Microscopy (Axiostar model plus, ZEISS), x200 magnification.

\section{Antibacterial activity assay}

Antibacterial activity was tested by means of a standard agar plate diffusion assay. Gram positive Staphylococcus aureus (CCBM 0324) and Gram negative Escherichia coli bacterial strains obtained from the Culture Collection of Microorganisms of Bahia (CCMB), Laboratory of Microbiology, University Estadual de Santa Cruz, Ilhéus, Bahia) were used. Tests were repeated and then calculated at Minimum Inhibitory Concentration (MIC). MIC as recommended by the Institute of Clinical and Laboratory Standards (CLSI, 2007) and adapted ${ }^{9}$. Evaluation of antitumor activity was done by determining the cell growth curve in the presence of the leaf and resin extract at concentrations of $0.1,1$ and $10 \mathrm{mg} / \mathrm{mL}$ ethanolic extracts of mangosteen. 


\section{Antimicrobial test agar diffusion}

The antimicrobial test agar diffusion technique was performed by the double layer well described by Groove and Randall $^{12}$ with adaptations. For the test we used a strain of Staphylococcus aureus obtained from the microbiology laboratory at the UESC. Initially prepared petri dishes containing $25 \mathrm{~mL}$ of Mueller-Hinto (MH) agar (HIMEDIA $($ ) for further use. Also prepared tubes containing $12.5 \mathrm{~mL}$ of $\mathrm{MH}$ agar, which were placed in a water bath (model $3618 / 4 \mathrm{D}$, New Ethics ${ }^{\circledR}$ ) at $50^{\circ} \mathrm{C}$ to prevent solidification until the time of the procedure. After growth on $\mathrm{MH}$ agar culture medium, 5 or 6 colonies were inoculated into $2.5 \mathrm{~mL}$ of $\mathrm{MH}$ broth, incubated for at $37^{\circ} \mathrm{C}$ for $6 \mathrm{~h}$, to give a density of microorganisms equivalent to Mac Farland scale (0.5), analyzed in a spectrophotometer (V1600, for analysis ${ }^{\circledR}$ ) at $600 \mathrm{~nm}$, which corresponds to $1,5 \times 10^{8}$ cells $/ \mathrm{mL}$. To perform the procedure, the total volume of the inoculum was transferred to the test tube containing $12.5 \mathrm{~mL}$ of $\mathrm{MH}$ agar no solidified and immediately after mixing, was transferred to Petri dish previously prepared with agar base, left to stand in laminar flow to solidify. Then, there were perforations (holes) with straws sterile $6 \mathrm{~mm}$, which were filled with $40 \mu \mathrm{L}$ of mangosteen extract $(100,10$ and $1 \mathrm{mg} / \mathrm{mL})$, positive control (penicillin 1,200.000 IU) and negative control (DMSO). The plates remained at room temperature for $2 \mathrm{~h}$ in laminar flow, for the diffusion of the mangosteen extract. Subsequently, they were incubated at $37^{\circ} \mathrm{C}$ in a bacteriological incubator. The zones of growth inhibition were measured with a millimeter ruler in periods 24 and $48 \mathrm{~h}$ after mangosteen extract treatment.

\section{Cell culture}

The mouse melanoma B16-F10 cell line was purchased from Rio de Janeiro Cell Bank (BCRJ/UFRJ). The cells were maintained at $37^{\circ} \mathrm{C}$ in an incubator with a humidified atmosphere of $5 \% \mathrm{CO}_{2}$ and cultured in DMEM/F12 supplemented with $10 \%$ heat-inactivated FBS, streptomycin $(100 \mu \mathrm{g} / \mathrm{mL})$ and penicillin (100 units/mL).

\section{Cell viability assay}

The effects of mangosteen extract treatment on cell viability were determined by MTT assay, which is based on the reduction of a tetrazolium salt by mitochondrial dehydrogenase in viable cells. For all experimental groups, cells were seeded in 96-well plates at a density of $1 \times 10^{4}$ cells/well and treated with mangosteen extract concentration 1 to $80 \mathrm{mg} / \mathrm{mL}$ for $48 \mathrm{~h}$. After treatment, B16-F10 cells were briefly washed with PBS. A serumfree medium containing $50 \mu \mathrm{L}$ of MTT stock solution (2 mg/ $\mathrm{mL}$ ) was added to each well to reach a total reaction volume of $250 \mu \mathrm{L}$, and the plates were incubated for an additional at $37^{\circ} \mathrm{C}$ for $4 \mathrm{~h}$. Supernatants were aspirated, and the resulting formazan crystals were dissolved in $150 \mu \mathrm{L}$ isopropyl alcohol. Absorbance of the product was measured at $540 \mathrm{~nm}$ using a colorimetric MTT ELISA assay (VERSAmax Tunable microplate reader, Molecular Devices, CA, USA). The absorbance of the negative control was considered as corresponding to a viability of $100 \%$, and the values of treated cells were calculated as percentage of the control.

\section{Comet assay}

The alkaline comet assay was performed as described by Singh et al. (1988) ${ }^{13}$ was adapted as follows. The melanoma cell line (B16-F10) was subcultured and seeded in culture bottles. After the process trypsinization, they were transferred to $15 \mathrm{~mL}$ Falcon tubes, centrifuged at $1500 \mathrm{rpm}$ for $5 \mathrm{~min}$. Then, the supernatant was discarded and a new aliquot of fresh DMEM/ F12 medium was added. The cells were stored until the time of use. During the procedure, the cells were treated with different concentrations of the leaf extract of mangosteen $(1,000,100$, and $10 \mathrm{mg} / \mathrm{mL}$ ) and incubated for 1 hour in a humidified $37^{\circ} \mathrm{C}$ and $5 \% \mathrm{CO}_{2}$. After treatment, the cell suspension was subjected to centrifugation $1000 \mathrm{rpm}$ at $4^{\circ} \mathrm{C}$ for $5 \mathrm{~min}$. The supernatant was discarded and the pellet was resuspended (approximately $15 \mu \mathrm{L})$ by adding $95 \mu \mathrm{L}$ low melting agarose at $37^{\circ} \mathrm{C}(0.75 \%)$, mixing gently. The samples were transferred to two sheets with agarose precoating normal melting point of $1.5 \%$. The slides were covered with coverslips, and then taken to the refrigerator for a period of $10 \mathrm{~min}$, in sequence, the coverslips were removed carefully. The slides were then immersed in lysis solution (2.5 M NaCl, $100 \mathrm{mM}$ EDTA, $10^{\circ} \mathrm{mM}$ TRIS, $1 \%$ Triton X-100 and $10 \%$ DMSO, $\mathrm{pH}=10.0$ ) at $4^{\circ} \mathrm{C}$ for $12^{\circ} \mathrm{h}$ protected from light. After this time, immersed in the electrophoresis alkaline buffer $(300 \mathrm{mM} \mathrm{NaOH}$ and $1 \mathrm{mM}$ EDTA, $\mathrm{pH}>13.0)$ at $4{ }^{\circ} \mathrm{C}$ for $20 \mathrm{~min}$ and thus subjected to electrophoresis for $15 \mathrm{~min}$ at $25 \mathrm{~V}$ and $300 \mathrm{~mA}$. The slides were treated with neutralizing solution (0.4 M Tris-HCl, $\mathrm{pH}$ 7.5) for $15 \mathrm{~min}$. Subsequently, we performed two washes with distilled water for $10^{\circ} \mathrm{min}$. After neutralization, the slides were dried in an oven overnight at $37^{\circ} \mathrm{C}$, fixed with a solution of $1 \%$ acetic acid for $10 \mathrm{~min}$. For coloring material was used solution of $0.05 \%$ ammonium nitrate, $0.05 \%$ silver nitrate, $0.075 \%$ formaldehyde and $0.125 \%$ tungstosílicico acid ${ }^{14}$. The slides were analyzed in photonic microscope (model Axiostar 
plus, ZEISS) at $10 \mathrm{X}$ magnification. Images of 100 randomly selected cells (50 cells from each of two replicate slides). Cells were scored visually according to tail size (from undamaged - 0 , to maximally damaged -4 ). Visual scoring of comets is a valid evaluation method determined by international guidelines and recommendations for the comet assay ${ }^{14,15}$.

\section{Statistical analysis}

Data are presented as mean $\pm \mathrm{SD}$ of four independent experiments. Statistical analysis among groups was performed by one-way analysis of variance (ANOVA) followed by the StudentNewman-Keuls Multiple Range Test. GraphPad Prism v.3.0 software was used, $\mathrm{p}<0.05$ was considered to be statistically significant.

\section{Results}

\section{Fruit and leaf anatomy and histochemistry}

The analysis of paraffin-embedded sections and stained with Astra Blue and Safranin demonstrated the presence of large amounts of secretory ducts in the pericarp of fruit, primarily in the mesocarp (Figure 1 A, B).

In the evaluation of histochemical reactions were identified in secretory parenchyma of the central rib, whose contents exhibited the same appearance oxidation occurring in the pericarp (Figure $1 \mathrm{C}$ ) the region ducts.

The reaction with Lugol was positive for starch that can be observed in the parenchyma cells of the vascular tissue in the midrib of the leaf. The reaction to Sudam III showed not well defined, with characteristic reaction in the cuticle and uncertainty as to the content of the ducts as seen in fruit. At midrib was also observed the presence of calcium oxalate crystals.

\section{Antimicrobial activity}

The agar diffusion test was used for antimicrobial activity against Staphylococcus aureus and Escherichia coli strains of the ethanolic extract of resin (Figure 2A), leaves (Figure 2B) and pericarp (Figure 2C). For these extracts, the minimum inhibitory concentration (MIC) was also determined, Chart 1.
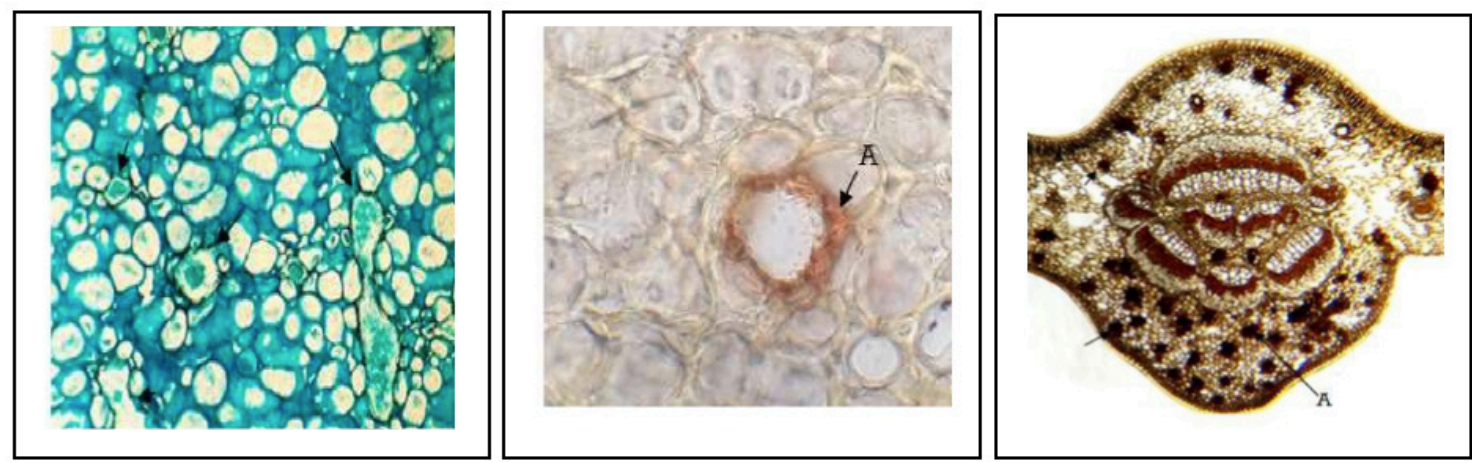

FIGURE 1 - (A) Cross-section of Garcinia mangostana L. (mangosteen) fruit showing several secretory ducts (arrows). (B) Positive reaction to Sudam III on the lining epithelial cells of secretory ducts. (C) Transverse section of the leaf midrib showing ferric chloride reaction.
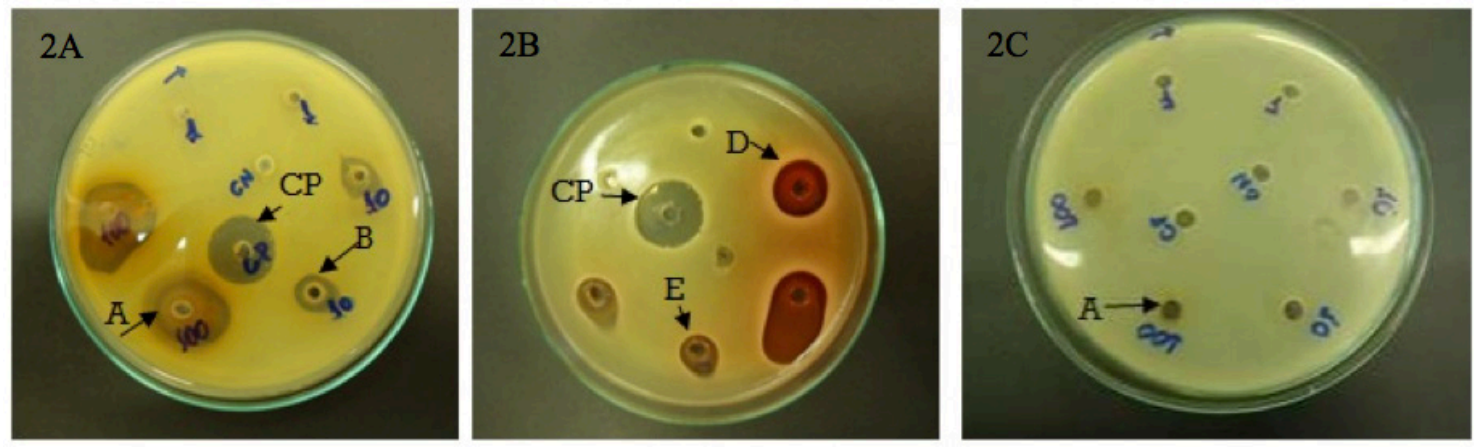

FIGURE 2 - A. Agar diffusion test in the mangosteen pericarp showing the inhibition of each well: $100^{\circ} \mathrm{mg} / \mathrm{mL}(\mathrm{A}) ; 10^{\circ} \mathrm{mg} / \mathrm{mL}(\mathrm{B}) ; \mathrm{positive}$ control (PC). B. Agar diffusion test of mangosteen leaf showing the inhibition of each well: $100^{\circ} \mathrm{mg} / \mathrm{mL}$ (D); $10^{\circ} \mathrm{mg} / \mathrm{mL}$ (E); positive control (PC). C. Agar diffusion test of mangosteen resin showing the inhibition of each well: $100^{\circ} \mathrm{mg} / \mathrm{mL}^{\circ}$ (A); positive control (PC). 


\section{Agar diffusion test analysis}

Chart 1. Agar diffusion test result - perforation technique (holeplate)

\begin{tabular}{|c|c|c|c|c|c|c|c|c|c|c|}
\hline X & \multicolumn{3}{|c|}{ PERICARP } & \multicolumn{3}{|c|}{ RESIN } & & LEA & & $\mathrm{CP}$ \\
\hline Conc. & $1 \mathrm{mg}$ & $10 \mathrm{mg}$ & $100 \mathrm{mg}$ & $1 \mathrm{mg}$ & $10 \mathrm{mg}$ & $100 \mathrm{mg}$ & $1 \mathrm{mg}$ & $10 \mathrm{mg}$ & $\mathrm{mg}$ & \\
\hline $\begin{array}{l}\text { Halo } \\
\text { (mm) }\end{array}$ & $\mathrm{N}$ & $4 \mathrm{~mm}$ & & $\mathrm{~N}$ & $\mathrm{~N}$ & & $\mathrm{~N}$ & $3 \mathrm{~mm}$ & $5 \mathrm{~mm}$ & $8 \mathrm{mr}$ \\
\hline
\end{tabular}

\section{Cell viability analysis}

Antiproliferative and cytotoxic effects of ethanolic extract of mangosteen in B16 - F10 cells. MTT viability test showing the B16-F10 cells treated with ethanolic extract of mangosteen (Figure 3).

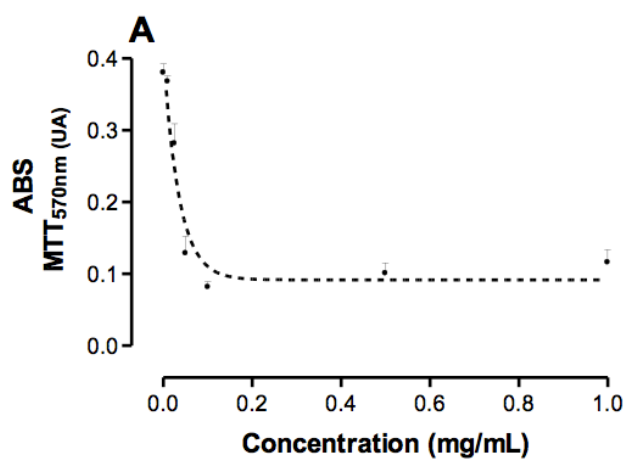

- Mangosteen leaf

B

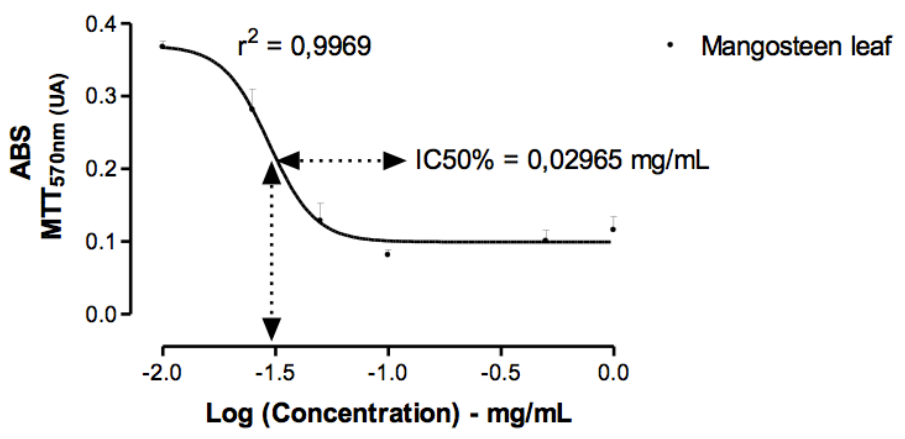

FIGURE 3 - Antiproliferative and cytotoxic effects of ethanolic extract of mangosteen in B16 - F10 cells. MTT viability test showing the B16-F10 cells treated for $48 \mathrm{~h}$ with different concentrations of extract $(0-1 \mathrm{mg} /$ $\mathrm{mL}$ ) (A) and after treatment with extract concentration up to $5 \mathrm{mg} / \mathrm{mL}$ significantly reduced the number of cells $(p<0.05)$. (B) IC50 $=0.02965$ $\mathrm{mg} / \mathrm{mL}$. The MTT data shown are performed in triplicates. Results are means \pm S.E.M from four independent experiments (*statistically significant against the control for $\mathrm{p}<0.05)$.

\section{Genotoxicity analysis by comet assay}

The comet assay with ethanolic extract mangosteen leaf showed apoptosis induction in B16-F10, which was evidenced by DNA fragmentation and formation of apoptotic bodies mainly at the concentration of $1 \mathrm{mg} / \mathrm{mL}$ (Figure 4).
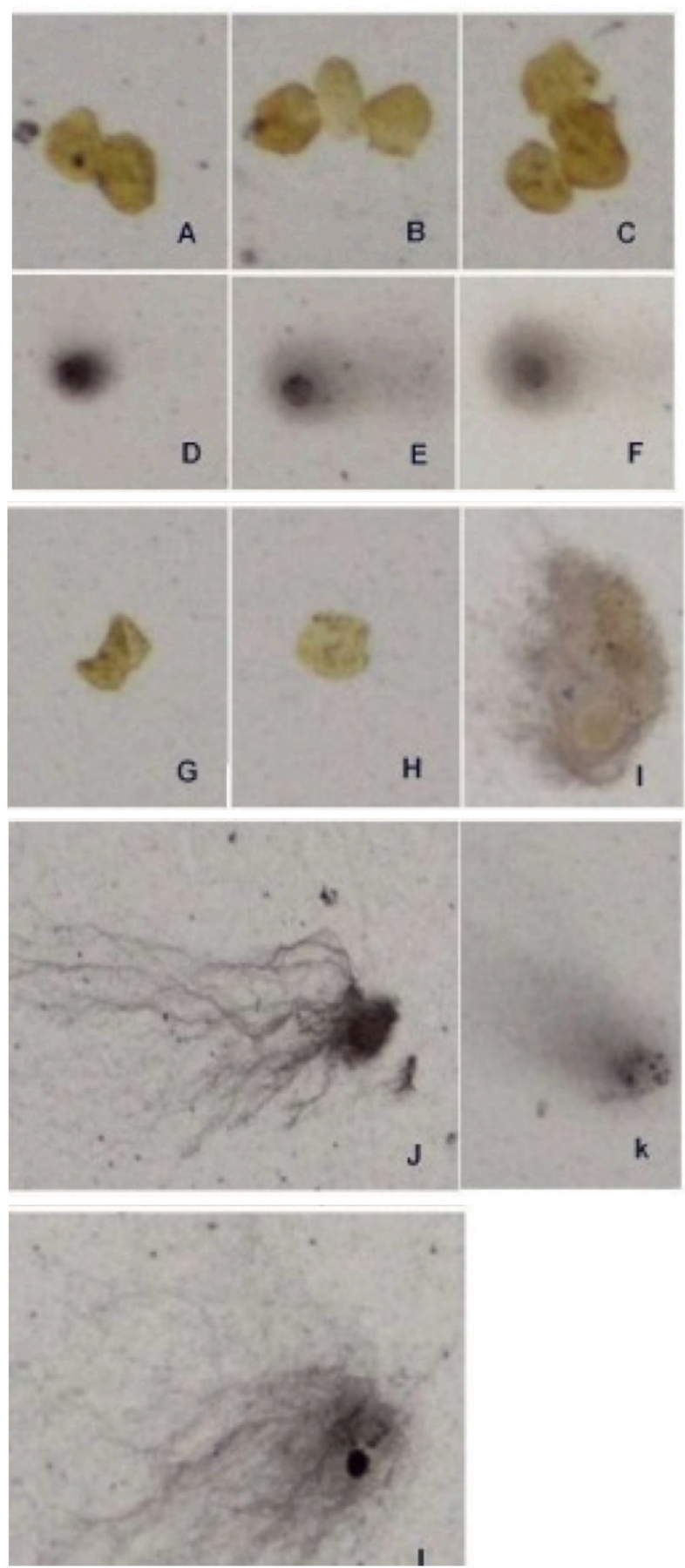

FIGURE 4 - A, B, C. Photomicrograph B16-F10 cells intact observed by microscopy optical, x400 magnification. D, E, F. Photomicrograph B16-F10 cells stimulated with Hydrogen Peroxide (positive control) with the scattering of fragments DNA of the cells. G, H, I. Photomicrograph cells B16-F10 stimulated $0.01 \mathrm{mg} / \mathrm{mL}$ of extract mangosteen leaf identifies a small degree of fragmentation and scattering of fragments DNA. I, J, L. Photomicrograph of cells B16-F10 stimulated $0.1 \mathrm{mg} / \mathrm{ml}$ of extract mangosteen leaf identifies the intense fragmentation and scattering of fragments DNA. Observe it extensive syrup comet consisting of DNA fragments. K. B16-F10 cells stimulated $1 \mathrm{mg} / \mathrm{mL}$ of extract mangosteen leaf identified intense fragmentation and scattering of DNA. Observer more points corresponding to the dark formation of apoptotic bodies. 


\section{Discussion}

Malignant melanoma is a cancer with a high incidence, malignancy and poor prognosis. This cancer is highly metastatic and high mortality rate. Currently, there are no methods or effective drugs for treatment and thus new methods are necessarily expected ${ }^{1,2}$

Malignant melanoma cells exhibit enhanced survival and proliferation capabilities. One of the most important reasons for this is antiapoptosis capacity, which is the predominant problem for clinical tolerance of chemotherapy drugs. Therefore, the identification of an effective drug has been the focus of melanoma treatment ${ }^{1,2}$. Search for new chemopreventive and antitumor agents that are more effective but less toxic has kindled great interest in phytochemicals. Ethanolic extract Garcinia mangostana L. fruit is one such compound which was used in this study. Garcinia mangostana L is a herbal remedy with promising anticancer properties ${ }^{10}$.

Asinelli et $a l .{ }^{16}$ in his work on the ontogeny of Garcinia gardneriana species found in southern Brazil, observed numerous secretory ducts and vascular bundles in the ovarian mesophyll, so that the diameter of the ducts increased from the periphery to the center noted that the changes anatomical suffered by this species during development is reported by other authors in species of Clusiaceae family. Souza ${ }^{17}$ affirms that for fruits of ovarian origin of the flower, the mesocarp come from ovarian mesophyll, which underlies the results with reference to the earlier work, indicating the presence of ducts as a feature throughout this period of fruit development. Roth ${ }^{18}$ confirms the Clusiaceae family as being characterized by the presence of peculiar secretory structures.

For histochemical reactions of the fruit, the pericarp was observed oxidation of this inside the secretory ducts in cuts-control content, interfering with the parameter for evaluating the results. Dorly et al. ${ }^{19}$ identified as a yellow latex content of secretory ducts present in mangosteen. In young fruit there is a high concentration of tannins, triterpenoids and flavonoids in the pericarp ducts. Roth $^{18}$ points out that the brown color of immature fruit when cut is due to the oxidation of tannins.

As macroscopic aspect, the resin presents a yellowish color after transection of fresh fruit. Compounds xanthophylls are yellow ${ }^{18}$. Feng et al. ${ }^{20}$ indicate the diversity of polipreniladosxanthonóides components that have been isolated from gamboge resin, which possibly explains the characteristic color of this substance. The epithelial cells lining the secretory ducts showed a positive reaction for Sudam III. These cells contain a high density of organelles such as plastids, mitochondria and vesicles of the Golgi complex ${ }^{19}$. The physiological characteristics of these cells may show a positive reaction to Sudam III.
When cross-sectional Garcinia mangostana sheet, it was observed with the naked eye similar to gamboge resin present in the pericarp exudate. In the evaluation of histochemical reactions were identified in secretory parenchyma of the central rib, whose contents exhibited the same appearance oxidation occurring in the pericarp the region ducts. Dorly et al. ${ }^{19}$ confirmed the presence of secretory ducts gamboge resin parenchymal tissue in the midrib and in the intercellular space between the spongy mesophyll cells. This aspect oxidized caused uncertainty in the identification of a positive reaction, ferric chloride, since the characteristic color is similar in both.

The reaction was positive for the Lugol, can be observed in black-bluish in midrib, featuring positivity. The reaction to Sudam III showed not well defined, with characteristic reaction in the cuticle and uncertainty as to the content of the ducts as indicated in. At midrib was also observed in the presence of calcium oxalate crystals within cells.

Our results show that the rate of proliferation of B16-F10 cells is significantly inhibited by various concentrations of ethanolic extract mangosteen. fruit $(0-1 \mathrm{mg} / \mathrm{mL})$. Following treatment of B16-F10 cells with $10 \mathrm{mg} / \mathrm{mL}$ ethanolic extract of mangosteen fruit for $48 \mathrm{~h}, \mathrm{~B} 16-\mathrm{F} 10$ cells proliferation rate was only $45 \%$.

To evaluate the genotoxic potential of the ethanolic extract mangosteen, we performed the comet assay. The comet assay technique use microgel for detecting DNA fragments. The larger number of double strand fragments is greater migration pattern (syrup) seen by Singh et al. ${ }^{13}$ with better definition in alkaline conditions. The technique of Single Cell Gel Electrophoresis Assay (SCGE) shows the microscope imaging of scattering fragments of DNA became known by Comet Assay. This technique presents to the small number of cells, levels of sensitivity to DNA damage at low cost.

Moreover, the ethanolic extract mangosteen fruit exhibited a genotoxic effect on the B16-F10 cells. The extract of mangosteen induced apoptosis in B16-F10 cells, seen by DNA fragmentation in the comet assay, formation of apoptotic bodies mainly for the concentration of $1 \mathrm{mg} / \mathrm{mL}$ It was able to induce fragmentation in DNA and apoptosis the growth of tumor cells in experimental model systems, but little is known about its potential as an adjuvant chemotherapeutic agent ${ }^{11,21}$. Especially considering the antitumoral activity, this fruit can have a major role in the anticancer therapy ${ }^{11,22}$.

The ethanolic extract of mangosteen fruit showed bacterial growth inhibition for Staphylococcus aureus compared to the positive control Minimum Inhibitory Concentration 
(MIC), $1 \mathrm{mg} / \mathrm{mL}$ determines the lowest concentration that is unanswered to inhibit bacterial growth. Thus, we investigated the bacterial susceptibility of gram-positive Staphylococcus aureus to the ethanolic extract of mangosteen. The choice of these microorganisms for the experiments is associated with the routine use of these strains for evaluation of antimicrobial activity. Moreover, these bacteria is human pathogen commonly isolated in Brazilian hospitals, representing $22.8 \%$ of isolates and often acquire resistance to antibiotics used ${ }^{23}$.

Thus, the search for new antibacterial agents is important for infection control. Our results show that the ethanolic extract of mangosteen has antimicrobial activity, inhibiting the growth of gram-positive bacteria. The ethanolic extract of mangosteen showed MIC ranging $1 \mathrm{mg} / \mathrm{mL}$ and $10 \mathrm{mg} / \mathrm{mL}$, showing greater effectiveness against Staphylococcus aureus strain where it exhibited a similar pattern to that caused by the antibiotic Ampicillin, positive control. These data corroborate others authors reported that the antimicrobial activity of the ethanolic extract of mangosteen, showing that its compounds may exhibit potent antibiotic activity against human pathogens ${ }^{24}$.

The inhibitory of microbial growth may be attributed to the presence of phenolic compounds in the plant. There is evidence that the ethanolic extract of mangosteen can also submit antituberculosis action, inhibiting the growth of Mycobacterium turbeculosis ${ }^{18}$. Moreover, conducted studies demonstrating satisfactory for antihelmintic activity with aqueous and ethanolic extracts of mangosteen fruit. Although we found an inhibitory effect against pathogenic microorganisms, other studies should be performed to confirm and isolate the secondary metabolites that exhibit antimicrobial activity ${ }^{19}$.

\section{Conclusions}

Garcinia mangostana L (mangosteen) fruit is widely used in alternative medicine for the treatment and prevention of tumors. Currently, there are many pre-clinical trials (animal model or in vitro). These studies have opened new perspectives for the understanding and medical use of this plant. Randomized clinical trials have to be performed to conclusive determination of their effects on human disease. The results obtained with the evaluation of the biological activity of the ethanolic extracts of the fruit, leaves and resin of mangosteen corroborate previous studies concerning its antimicrobial activity. Another observed activity was the potent genotoxic action of the leaf extract, after short exposure of the B16-F10 melanoma cell line. The presence of antimicrobial activity and genotoxic potential in leaves makes further research possible due to the abundance of leaves on the mangosteen tree. The phytocompounds from mangosteen may provide promising improvements in the therapeutic approach to infectious diseases and melanoma treatment.

\section{References}

1. Jerant AF, Johnson JT, Sheridan CD, Caffrey TJ. Early detection and treatment of skin cancer. Am Fam Physician. 2000;62(2):35768, 375-6, 381-2.

2. Lasithiotakis KG, Petrakis IE, Garbe C. Cutaneous melanoma in the elderly: epidemiology, prognosis and treatment. Melanoma Res. 2010 Jun;20(3):163-70.

3. Jemal A, Siegel R, Xu J, Ward E. Cancer statistics, 2010. CA Cancer J Clin. 2010 Sep-Oct;60(5):277-300.

4. Rajamanickam S, Agarwal R. Natural products and colon cancer: current status and future prospects. Drug Dev Res. 2008 Nov 1;69(7):460-71.

5. Sacramento CK, Coelho EJ, Carvalho JEU de, Muller $\mathrm{CH}$, Nascimento WMO do. Cultivo do mangostão no Brasil. Rev. Bras Fruticultura. 2007Abr;29 (1):195-203.

6. Almeyda N, Martin FW. Cultivation of neglected tropical fruits with promise: the mangosteen. Mayaguez: Agricultural Research Service. U.S. Department of Agriculture. 1976.

7. Muller CH. A cultura do mangostão. Brasília: EMBRAPA - SPI; 1995.

8. Jung HA, Su BN, Keller WJ, Mehta RG, Kinghorn AD.Antioxidant Xanthones from the pericarp of Garcinia mangostana. J Agric Food Chem.2006 Fev;54(6):2077-82.

9. Nguyen PT, Marquis RE. Antimicrobial actions of asur-mangostin against oral streptococci. Can J Microbiol. 2011 Mar;57(3):217-25.

10. Gnerre C, Thull U, Gaillard P, Testa B, Fernandez E, Silva F, Pinto M, Pinto MM, Wolfender JL, Hostettmann K, Cruciani, G. Natural and synthetic xanthones as monoamine oxidase inhibitors: biological assay and 3D-DSAR. Helvitica Chimica Acta.2001;84:552-70.

11. Lee SB, Chen CM. United States Patent. Compounds isolated from Gamboge resin having activity in inhibiting the growth of tumor/ cancer cells and pharmaceutical compositions comprising the same. No. US 7,138,428, Nov. 21, 2006.

12. Grove DC, Randall WA. Assay methods of antibiotics, a laboratory manual. New York: Medical Encyclopedia, 1995. (Antibiotics monographs, 2)

13. Singh NP, McCoy MT, Tice RR, Schneider EL. A simple technique for quantitation of low levels of DNA damage in individual cells. Exp Cell Res. 1988 Mar;175(1):184-91.

14. Hartmann A, Speit G. The contribution of cytotoxicity to DNAeffects in the single cell gel test (comet assay). Toxicol Lett. 1997;90:183-8.

15. Burlinson B, Tice RR, Speit G, Agurell E, Brendler-Schwaab SY, Collins AR, Escobar P, Honma M, Kumaravel TS, Nakajima M, Sasaki YF, Thybaud V, Uno Y, Vasquez M, Hartmann A; In Vivo Comet Assay Workgroup, part of the Fourth International Workgroup on Genotoxicity Testing. Fourth International Workgroup on Genotoxicity testing: results of the in vivo Comet assay workgroup. Mutat Res. 2007;627:31-5.

16. Asinelli MEC, Souza MC, Mourão KSM. Fruit ontogeny of Garcinia gardineriana (Planch \& Triana) Zappi (Clusiaceae). Acta Botanica Bras. 2011 Jan/Mar;25(1):43-52.

17. Souza LA. Morfologia e Anatomia vegetal: célula, tecidos, órgãos e plântulas. Ponta Grossa: UEPG; 2003.

18. Roth I. Fruits of angiosperms. Gebr.Borntraeger; 1977. 
19. Dorly S, Rodoedhypoerwanto J. secretory duct structure and phytochemistry compounds of yellow latex in mangosteen fruit. HAYATI J Biosciences. 2008;15(3):99-104.

20. Feng F, Liu WY, Chen YS, Guo QL, You QD. Five novel prenylatedxanthones from Resina Garciniae. J Asian Nat Prod Res. 2007 Sep-Dec;9(6-8):735-41.

21. Matsumoto K, Akao Y, Kobayashi E, Ohguchi K, Ito T, Tanaka T, Nozawa $Y$. Induction of apoptosis by xanthones from mangosteen in human leukemia cell lines. J Nat. Prod. 2003 Jul;66(8):1124-7.

22. Akao y, Nakagawa Y, Nozawa Y. Anti-cancer effects of xanthones from pericarps of mangosteen. Int J Mol Sci. 2008 Mar;9 (3):33570.

23. Sader HS, Mendes RE, Gales AC, Jones RN, Pfaller MA, Zoccoli C, Sampaio J. Perfil de sensibilidade a antimicrobianos de bactérias isoladas do trato respiratório baixo de pacientes com pneumonia internados em hospitais brasileiros - Resultados do Programa SENTRY, 1997 e 1998. J Bras Pneumol. 2001;27(2):59-67.

24. Jung HA, Su BN, Keller WJ, Mehta RG, Kinghorn AD. Antioxidant Xanthones from the pericarp of Garcinia mangostana. J Agric Food Chem. 2006 Fev;54(6):2077-82.

\section{Acknowledgements}

To the Skin Cell Culture Laboratory, Plastic Surgery Division, Department of Surgery, UNIFESP.

\section{Correspondence:}

Lucimar Pereira de França

Departamento de Ciências Biológicas

Laboratório de Biofísica Celular e Molecular

Universidade Estadual de Santa Cruz-UESC

Rodovia Jorge Amado, Km 16

45662-900 Ilhéus - Bahia Brazil

Tel./Fax: (55 73)3680-5360

lucimarfrancap@gmail.com

jeronimopf@gmail.com

National Council for Scientific and Technological Development (CNPq), Bahia Research Foundation (FAPESB) and ETENE/FUNDECI- Banco do Nordeste do Brasil

IResearch performed at Laboratory of Molecular and Cellular Biophysics, State University of Santa Cruz (UESC), Brazil. 